ELECTRICAL DRAWING I 
Macmillan Technician Series

P. Astley, Engineering Drawing and Design II

P. J. Avard and J. Cross, Workshop Processes and Materials I

G. D. Bishop, Electronics II

G. D. Bishop, Electronics III

J. C. Cluley, Electrical Drawing I

J. Elliott, Building Science and Materials

John G. Ellis and Norman J. Riches, Safety and Laboratory Practice

D. E. Hewitt, Engineering Science II

P. R. Lancaster and D. Mitchell, Mechanical Science III

R. Lewis, Physical Science I

Noel M. Morris, Digital Techniques

Noel M. Morris, Electrical Principles II

Noel M. Morris, Electrical Principles III

A. Simpson, Light Current Electrical Applications III 


\section{ELECTRICAL DRAWING I}

J. C. Cluley 
All rights reserved. No part of this publication may be reproduced or transmitted, in any form or by any means, without permission.

First published 1979 by

THE MACMILLAN PRESS LTD

London and Basingstoke

Associated companies in Delhi Dublin

Hong Kong Johannesburg Lagos Melbourne

New York Singapore and Tokyo

Typeset in 10/12 Times

British Library Cataloguing in Publication Data

Cluley, John Charles

Electrical drawing I.-(Macmillan technician series).

1. Electric drafting

I. Title

$604^{\prime} .2^{\prime} 62131042 \quad$ TK431

ISBN 978-0-333-27023-3

DOI 10.1007/978-1-349-04793-2

This book is sold subject to the standard conditions of the Net Book Agreement.

The paperback edition of this book is sold subject to the condition that it shall not, by way of trade or otherwise, be lent, resold, hired out, or otherwise circulated without the publisher's prior consent in any form of binding or cover other than that in which it is published and without a similar condition including this condition being imposed on the subsequent purchaser. 


\section{Contents}

Foreword

Preface

1. Introduction
1.1 Types of Drawing
1.2 Mechanical Drawings
1.3 Symbolic Drawings
1.4 Graphs and Charts
1.5 The User's Needs
1.6 Types of Line
1.7 Sizes of Drawing and Lettering
1.8 Reproduction of Drawings

\section{Orthographic Drawings}
2.1 Types of Projection
2.2 Hidden Lines
2.3 Sectional Views
2.4 Auxiliary Views

\section{Pictorial Drawings}

3.1 Other Types of Projection

3.2 Isometric Projection

3.3 Oblique Projection

3.4 Cutaway Drawings

3.5 Exploded Views

3.6 Sheet Metal Construction

\section{Dimensioning}

4.1 Principles of Dimensioning

4.2 Projection Lines
4.3 Datum Lines

4.4 Functional and Non-functional Dimensions

4.5 Examples of Dimensioning

4.6 Dimensions from Drawings

5. Mechanical Symbols and Abbreviations

5.1 Conventional Representation of Detail

6. Block Diagrams

6.1 The Function of Block Diagrams

6.2 Block Diagram Layout

6.3 Standard Block Symbols

6.4 Logic Symbols

6.5 British Standard Symbols

6.6 Other Standards

7. Circuit Diagrams

40

7.1 General Principles

7.2 Connection Lines and Connectors

40

40

7.3 Symbols for Passive Components

7.4 Symbols for Contacts, Relays and Switches

42

7.5 Detached Contact Convention

43

45

7.6 Symbols for Transistors and Valves $\quad 46$

7.7 Symbols for Transducers 49

7.8 Drawing Circuit Diagrams 49

7.9 Standard Component Layouts 50

7.10 Examples of Circuit Diagrams $\quad 52$

7.11 Producing Diagrams from Equipment Layouts 53

8. Equipment Design 58

8.1 Design Assessment $\quad 58$

8.2 Design Criteria 58

8.3 Component Selection $\quad 60$

8.4 Types of Resistor $\quad 60$

8.5 Types of Capacitor $\quad 60$

8.6 Insulating Materials 61

8.7 Low-voltage Insulation 62 
8.8 Materials for High Temperatures and High Frequencies

8.9 Equipment Testing

8.10 Assured Quality Components

Appendix $A-$ Standards in Electrical Drawing

Appendix $B-$ British and International Standards 


\section{Foreword}

This book is written for one of the many technician courses now being run at technical colleges in accordance with the requirements of the Technician Education Council (TEC). This Council was established in March 1973 as a result of the recommendation of the Government's Haslegrave Committee on Technical Courses and Examinations, which reported in 1969. TEC's functions were to rationalise existing technician courses, including the City and Guilds of London Institute (C.G.L.I.) Technician courses and the Ordinary and Higher National Certificate courses (O.N.C. and H.N.C.), and provide a system of technical education which satisfied the requirements of 'industry' and 'students' but which could be operated economically and efficiently.

Four qualifications are awarded by TEC, namely the Certificate, Higher Certificate, Diploma and Higher Diploma. The Certificate award is comparable with the O.N.C. or with the third year of the C.G.L.I. Technician course, whereas the Higher Certificate is comparable with the H.N.C. or the C.G.L.I. Part III Certificate. The Diploma is comparable with the O.N.D. in Engineering or Technology, the Higher Diploma with the H.N.D. Students study on a part-time or block-release basis for the Certificate and Higher Certificate, whereas the Diploma courses are intended for full-time study. Evening study is possible but not recommended by TEC. The Certificate course consists of fifteen Units and is intended to be studied over a period of three years by students, mainly straight from school, who have three or more C.S.E. Grade III passes or equivalent in appropriate subjects such as mathematics, English and science. The Higher Certificate course consists of a further ten Units, for two years of part-time study, the total time allocation being 900 hours of study for the Certificate and 600 hours for the Higher Certificate. The Diploma requires about 2000 hours of study over two years, the Higher Diploma a further 1500 hours of study for a further two years.

Each student is entered on to a Programme of study on entry to the course; this programme leads to the award of a Technician Certificate, the title of which reflects the area of engineering or science chosen by the student, such as the Telecommunications Certificate or the Mechanical Engineering Certificate. TEC have created three main Sectors of responsibility: 
Sector A responsible for General, Electrical and Mechanical Engineering

Sector B responsible for Building, Mining and Construction Engineering

Sector C responsible for the Sciences, Agriculture, Catering, Graphics and Textiles.

Each Sector is divided into Programme committees, which are responsible for the specialist subjects or programmes, such as $\mathrm{A} 1$ for General Engineering, A2 for Electronics and Telecommunications Engineering, A3 for Electrical Engineering, etc. Colleges have considerable control over the content of their intended programmes, since they can choose the Units for their programmes to suit the requirements of local industry, college resources or student needs. These Units can be written entirely by the college, thereafter called a college-devised Unit, or can be supplied as a Standard Unit by one of the Programme committees of TEC. Assessment of every Unit is carried out by the college and a pass in one Unit depends on the attainment gained by the student in his coursework, laboratory work and an end-of-Unit test. TEC moderate college assessment plans and their validation; external assessment by TEC will be introduced at a later stage.

The three-year Certificate course consists of fifteen Units at three Levels: I, II and III, with five Units normally studied per year. A typical programme might be as follows.

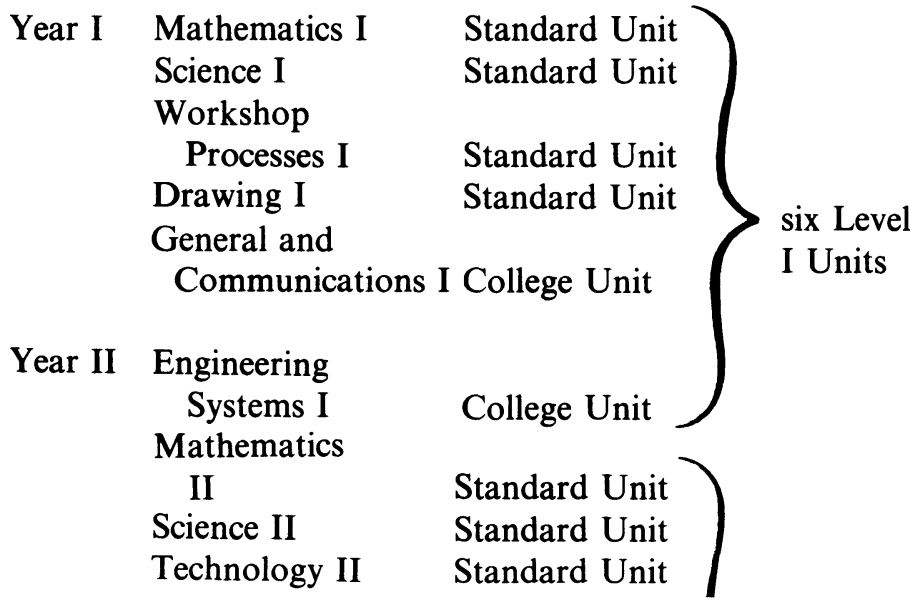

\begin{tabular}{|c|c|c|}
\hline $\begin{array}{c}\text { General and } \\
\text { Communi- } \\
\text { cations II }\end{array}$ & College Unit & $\begin{array}{l}\text { six Level } \\
\text { II Units }\end{array}$ \\
\hline $\begin{array}{l}\text { Industrial } \\
\text { Studies II }\end{array}$ & College Unit & \\
\hline $\begin{array}{l}\text { Engineering } \\
\text { Systems II }\end{array}$ & College Unit & \\
\hline $\begin{array}{l}\text { Mathematics } \\
\text { III } \\
\text { Science III } \\
\text { Technology III }\end{array}$ & $\begin{array}{l}\text { Standard Unit } \\
\text { Standard Unit } \\
\text { College Unit }\end{array}$ & $\begin{array}{l}\text { three Level } \\
\text { III Units }\end{array}$ \\
\hline
\end{tabular}

Entry to each Level I or Level II Unit will carry a prerequisite qualification such as C.S.E. Grade III for Level I or O-level for Level II; certain Craft qualifications will allow students to enter Level II direct, one or two Level I Units being studied as 'trailing' Units in the first year. The study of five Units in one college year results in the allocation of about two hours per week per Unit, and since more subjects are often to be studied than for the comparable City and Guilds course, the treatment of many subjects is more general, with greater emphasis on an understanding of subject topics rather than their application. Every syllabus to every Unit is far more detailed than the comparable O.N.C. or C.G.L.I. syllabus, presentation in Learning Objective form being requested by TEC. For this reason a syllabus, such as that followed by this book, might at first sight seem very long, but analysis of the syllabus will show that 'in-depth' treatment is not necessary - objectives such as 'states Ohm's law' or 'lists the different types of telephone receiver' clearly do not require an understanding of the derivation of the Ohm's law equation or the operation of several telephone receivers.

This book satisfies the learning objectives for one of the many TEC Standard Units, as adopted by many technical colleges for inclusion into their Technician programmes. The treatment of each topic is carried to the depth suggested by TEC, and in a similar way the length of the Unit (sixty hours of study for a full Unit), prerequisite qualifications, credits for alternative qualifications and aims of the Unit have been taken into account by the author. 


\section{Preface}

Teachers are frequently reminded that a well-chosen picture is worth a thousand words of text. When describing engineering devices and apparatus this number is surely a gross underestimate. Well-drawn diagrams and scaled drawings convey a wealth of information in a concentrated, precise and easily understood form. Any attempt to replace them by text alone would produce confusion in the reader and almost certainly ambiguity of purpose. For this reason technical drawings are an essential form of communication between engineers, for recording and specifying precisely the details of devices and apparatus.

This book provides the core material required by all electrical and electronic engineers and is particularly intended to meet the requirements of the Electrical Drawing I Syllabus of the Technician Education Council (TEC U75/011).

The preparation and interpretation of engineering drawings and diagrams is a mainly practical activity. Consequently students are urged to supplement their reading of this book with plenty of practice at making drawings and diagrams, and studying carefully any examples which they encounter at work or in other technical studies. This will, I hope, help them to relate the principles given here to the work of professional engineers.

The engineering and drawing Standards mentioned in this book can be obtained from the British Standards Institution, 101 Pentonville Road, London N1 9ND. 